\title{
Decorative Pot Bougainvillea by Pruning and PP-333 Applications
}

\section{Gad, M.M.}

Ornamental Plants Dept., Fac. Agric., Assiut University, Egypt.

Mohamed.mohamd1@agr.au.edu.eg

Received on: 16/4/2019

Accepted for publication on: 9/5/2019

\begin{abstract}
Potted -bougainvillea plants too tall if not checked, so pruning and growthretarding paclobutrazol (PP-333) application are used to limit this growth to produce an acceptable and compacted foliage growth covered with dense flowers for a long periods to be a show pot-plant. Plants were pruned to have one or two branches (30 cm long) and sprayed twice with PP-333 at 0, 500 or $1000 \mathrm{ppm}$. Results indicated that the plant with one-branch showed a slight increase in height and significantly increased shoot length up to $24 \%$ higher than with twobranches. The later recorded an opposite trend as resulted in higher branch number per plant up to $14.6 \%$ over the plant have one-branch. Meanwhile, number of leaves and their areas were not affected. Although number of flower bracts were not affected by branch number, the plant with one-branch significantly increased their fresh weight was $60 \%$ higher than with two-branches.

Spraying with PP-333 significantly decreased plant height, shoot length and leaf area with increasing its concentration; thus the great reductions occurred by 1000ppm were 31.8, 51 and 49\% lower than control, respectively. The increase in shoot number was apparently associated with PP-333 at 500ppm, but leaf formation was greatly increased with either 500 or $1000 \mathrm{ppm}$. The first produced higher number and heavier fresh weight of flower bracts almost were 33 and $63 \%$ higher than a concentration of 1000ppm, respectively. Chlorophylls (a\&b) and total carbohydrates content in leaves were greatly accumulated by raising the branching and PP-333 concentration. The interaction effects among treatments declared that the best combination was resulted from the plants with twobranches sprayed twice with PP-333 at 500ppm that led to control the growth habit without losing its ability to grow.
\end{abstract}

Keywords: Bougainvillea glabra, Growth retardants, Paclobutrazol, Branching, Pruning.

\section{Introduction}

Bougainvillea shrubs are the most attractive plants for their heavy bright-flowering. They well grown in many warm climate regions and blossom several times throughout the year. The plant can be used as a potplant or a hanging-basket. Overly elongated of bougainvillea plants are spindly and unattractive (an important consideration with containergrown woody ornamentals). It is de- sirable to reduce its over growth with pruning and applying growth retardant to control the growth with the pot size, as well as it makes it easily handling. Kobayashi et al. (2007) demonstrated that the regular pruning is necessary to shape the plant and direct its growth because the shoots often grow vigorously and the flowers are borne on new growth. Calatayud et al. (2007) stated that the main objective of pruning is to maintain or 
develop a desired size or attractive plant shape especially woody ornamental plants.

Using PP-333 as the most attractive growth retarding substances to retard stem elongation, produce dark green leaves and indirectly affect flowering without formative effects. The persistence of the effects of PP-333 on the growth and flowering of many ornamental shrubs were reported by numerous investigators; Karaguzel and Ortacesme (2002), EL-Quesni et al. (2007) and Jaini et al. (2016) on bougainvilleas, ELSallami (2001) on poinsettia, Auda et al. (2002) on barleria, Singh (2002) on rose, Matsoukis and Chronopoulou-Sereli (2003) on Lantana camara, Ahmed Nazarudin (2012) on Hibiscus rosa-sinensis, Hussein (2013) on Cestrum nocturnum, and Heikal (2017) on Sanchezia nobilis.

The aim of this work was to select a useful technique involved in pruning and PP-333 application for commercial production of bougainvillea as a decorative pot-plant.

\section{Materials and Methods}

The present study was carried out at the Floricultural Nursery, Faculty of agriculture, Assiut University during two successive seasons of $2012 / 2013$ and 2013/2014 to define the most suitable combination of branch number and PP-333 concentration to produce a desirable potplant of Bougainvillea glabra cultivar Snow white.

In the first April of both seasons, healthy and vigorous plants (one-year-old) were carefully selected as being uniform in the size. Plants were grown singly into $25-\mathrm{cm}$ plastic pots filled with clay soil ( $\mathrm{pH} \mathrm{7.9)}$ and pruned to have one or two-branches; each $30 \mathrm{~cm}$ long.

Paclobutrazol [(2RS, 3RS)-1-(4chlorophenyl) -4, 4-dimethyl 1-2(1,2,4-triazole-1-ethanol)] was prepared as aqueous solution by diluting the chemical suspension at different concentrations in water ; 0 (control), 500 and $1000 \mathrm{ppm}$. The plants were sprayed twice with PP-333; the first at 6-weeks after planting and the second at 3-weeks interval. Paclobutrazol solutions were sprayed in the morning to the point of run-off using air compressed hand sprayer. All horticultural practices were similarly done whenever needed. Plants were grown under saran-house conditions (30\% light) until the end of experiment.

The experiment consisted of 6 treatments (two branching treatments $\mathrm{x}$ three PP-333 levels) were arranged in a split-plot design, branching treatments as main -plots and PP-333 concentrations as sub-plots. Each treatment contained 4 plants (pots) and replicated four times.

At the end of the experiment (mid-March) of both seasons, data were recorded on the vegetative and flowering parameters. Leaf pigments were estimated according to Vernon (1960) and total soluble carbohydrates percentage was determined according to Hansen and Moller (1975).

Data were statistically analyzed using Statistix 8.1 analytical software, and the mean were compared using a least significant difference (L.S.D.) test according to Snedecor and Cochran (1989). 


\section{Results and Discussion}

Vegetative growth parameters

Results clearly indicated that growth characteristics showed various responses to branching treatments and PP-333 concentrations (Table1). Obviously, number of shoots per plant and their lengths were significantly affected by branching treatments where as plants with twobranches produced higher shoot number than those of with onebranch. Meanwhile, this behavior was in direct contrast to that of shoot length since plants with one -branch produced taller shoots than those of with two-branches during the two seasons. There was a slight decrease in plant height obtained by plants with two-branches. Negligible increments were detected between branching treatments in relation to number of leaves and their areas. These results are in accordance with the findings of Kobayashi et al. (2007) who reported that pruning bougainvillea encourages the new growth on which the next flush of flowers will occur and reduce the size of plants, cut them back by about a third, removing all spindly and twiggy growth. Prune suckers from the plant's base to encourage top growth. In addition, Saifuddin et al. (2010) demonstrated that frequent pruning can be used to maintain plant growth and flower shoot initiation of bougainvillea.

Concerning the effect of PP-333 application, it was observed that plant height, shoot length and leaf area were significantly decreased with increasing PP-333 level; thus the great reductions occurred by $1000 \mathrm{ppm}$ were 31.8, 51 and 49\% (average of both seasons) lower than control, re- spectively. Significant increase in shoot number was apparently associated with PP-333 at 500ppm reached 2.4 and 2.1 -fold when it compared to $1000 \mathrm{ppm}$ during the first and second seasons, respectively. Both PP-333 levels of 500 and $1000 \mathrm{ppm}$ significantly increased number of leaves resulting in 12.5 and $17.7 \%$ higher than control in the first season, as well as 26 and $19 \%$ in the second one, respectively. Similar observations were reported by Karaguzel and Ortacesme (2002), EL-Quesni et al. (2007) and Jaini et al. (2016) on bougainvilleas, EL-Sallami (2001) on poinsettia, Auda et al. (2002) on barleria, Singh (2002) on rose, Ahmed Nazarudin (2012) on Hibiscus rosa-sinensis, and Heikal (2017) on Sanchezia nobilis. They concluded that the inhibitory effect of PP-333 on plant height and shoot length due to slow cell division and inhibit cell elongation.

Numerous researchers explained the mode of action of the growth retardants and their biosynthesis inside the plants. Sachs and Hackett (1972) postulated that in most species only internode length is inhibited as a result of reduced subapical meristematic activity, and others on apical meristematic function have been noted, and leaf and flower initiation may be inhibited nearly equally with stem elongation. In addition, Law and Hamilton (1989) stated that in all species the influence of exogenous growth retardants on shoot system inhibition is nearly completely acting against endogenous gibberellins and cytokinins which can inhibit the gibberellins-stimulated growth or inhibit cytokinin-stimulated growth. 
The interaction effects between branching treatments and PP-333 concentrations declared that the plants with two-branches sprayed with PP-333 at 1000ppm were found to be more compactness containing lower shoot number and smaller leaves than the other combinations. However, the plants with twobranches sprayed with PP-333 at $500 \mathrm{ppm}$ were more suitable for producing better plant height, more branch formation, and favored increasing the number and size of leaves.

\section{Flowering parameters}

It is noticed that number of flower bracts and their fresh weight were greatly responded to branching treatments and PP-333 levels (Table 1). Although number of flower bracts were not affected by branch number, the plants with one-branch significantly increased their fresh weight were 61 and 58\% higher than those with two-branches in the first and second seasons, respectively. These results indicated that there was not a direct relationship between number of flower bracts and their weight under branching treatments. Similar trend of these results agree with earlier observations by Saifuddin et al. (2010) who found that the maximum flower production per plant was induced after pruning the plants of Bougainvillea glabra.

With regard to PP-333 effects, it was noticed that number of flower bracts and their fresh weight were noticeably affected by PP-333. Both concentrations of 500 and $1000 \mathrm{ppm}$ significantly increased these flower characters compared to control. The most striking relationship is that as- sociated with PP-333 at 500ppm. This treatment was markedly higher than $1000 \mathrm{ppm}$ resulting in 31 and $35 \%$ for number, as well as 59 and $68 \%$ for weight in the first and second seasons, respectively. These results are in agreement with those obtained by EL-Sallami (2001) on poinsettia, Matsoukis and ChronopoulouSereli (2003) on Lantana camara, Ahmed Nazarudin (2012) on Hibiscus rosa-sinensis, Hussein (2013) on Cestrum nocturnum, Jaini et al. (2014 and 2016) on bougainvillea and Heikal (2017) on Sanchezia nobilis.

In this respect, Sachs and Hackett (1972) found that as a result of treatment with growth retardants, the flowering process may remain unaltered, be accelerated, or be delayed. On a typical woody plant, the time of flower initiation and anthesis were controlled by phytochrome, the photo-reversible pigments, which received the photo control pattern from the environment.

The interaction effects among the treatments cleared that the greatest flowering was resulted from plants with one or two-branches and sprayed with PP-333 at 500 followed by $1000 \mathrm{ppm}$.

\section{Leaf pigment}

It is quite clear that chlorophylls (a\&b) content in leaves mostly were significantly higher in plant with twobranches than those with one-branch in both seasons (Table 2). Meanwhile, carotenoids content were insignificantly affected. These results are in conformity with those reported by Saifuddin et al. (2010) on Bougainvillea glabra.

In respect of PP-333 effects, it was found that chlorophylls (a\&b) 
and carotenoids were significantly increased with increasing PP-333 concentration in the two seasons. These results are in harmony with those reported by EL-Sallami (2001) on poinsettia, Auda et al. (2002) on barleria, EL-Quesni et al. (2007) on bougainvillea, Ahmed Nazarudin (2012) on Hibiscus rosa-sinensis, Hussein (2013) on Cestrum nocturnum and Heikal (2017) on Sanchezia nobilis.

In this connection, Cathey (1964) attributed the increase in chlorophyll as a results of growth retardants application to their effects on the reduction of cell size by inhibition cell elongation, consequently the amount of leaf pigments were concentrated in a limited size. LeCain et al. (1986) concluded that Ficus benjamina leaves developing under the influence of PP-333 appeared darker green than in untreated plants by increasing the pigment plastids and maintaining full chlorophyll content in leaves which may be interpreted by a delay in senescence and retarding breakdown of chlorophylls.

The interaction effects indicated that the most effective combination in increasing chlorophylls $(\mathrm{a} \& \mathrm{~b})$ and carotenoids was obtained from plants with two-branches combined with PP-333 at $1000 \mathrm{ppm}$; the increases in these leaf pigments were almost 1.3-times higher than unsprayed ones in both seasons.

\section{Total carbohydrates}

Data cleared that total carbohydrates content in leaves of plants with two-branches was significantly higher than those with one-branch in the two seasons (Table 2).
With refer to PP-333 effect on leaf carbohydrates, the content was significantly increased with increasing PP-333 level. Accordingly, the increase occurred by $1000 \mathrm{ppm}$ reached 1.4-times higher than in control plants during both seasons. Clearly, these results also followed a similar pattern to chlorophyll results. These results are parallel to the results of EL-Sallami (2001) on poinsettia, Auda et al. (2002) on barleria, EL-Quesni et al. (2007) on bougainvillea and Hussein (2013) on Cestrum nocturnum. They concluded that the increase in total carbohydrates as a result of PP-333 application might be attributed to increase in photosynthesis activity, consequently producing more photosynthetic products leading to more carbohydrates accumulation.

The interaction effects among the treatments declared that the best combination in increasing leaf pigments (plant with two-branch + PP333 at $1000 \mathrm{ppm}$ ) was also positively reflected that on raising leaf carbohydrates to 1.4-times higher than unsprayed ones in the two seasons.

From the above mentioned results it could be noticed that there was a close relationship between the best growth and quality with compact growth and dense flowers, and the adequate level of PP-333 (500ppm) and the suitable branching (twobranches). So this combined treatment proved to be the best for producing plant of high quality of Bougainvillea glabra as a flowering potplant is considered commercially acceptable. 
Table 1. Effect of branch number and PP333 on vegetative growth and flowering parameters of bougainvillea plants during 2012/2013 and 2013 /2014 seasons

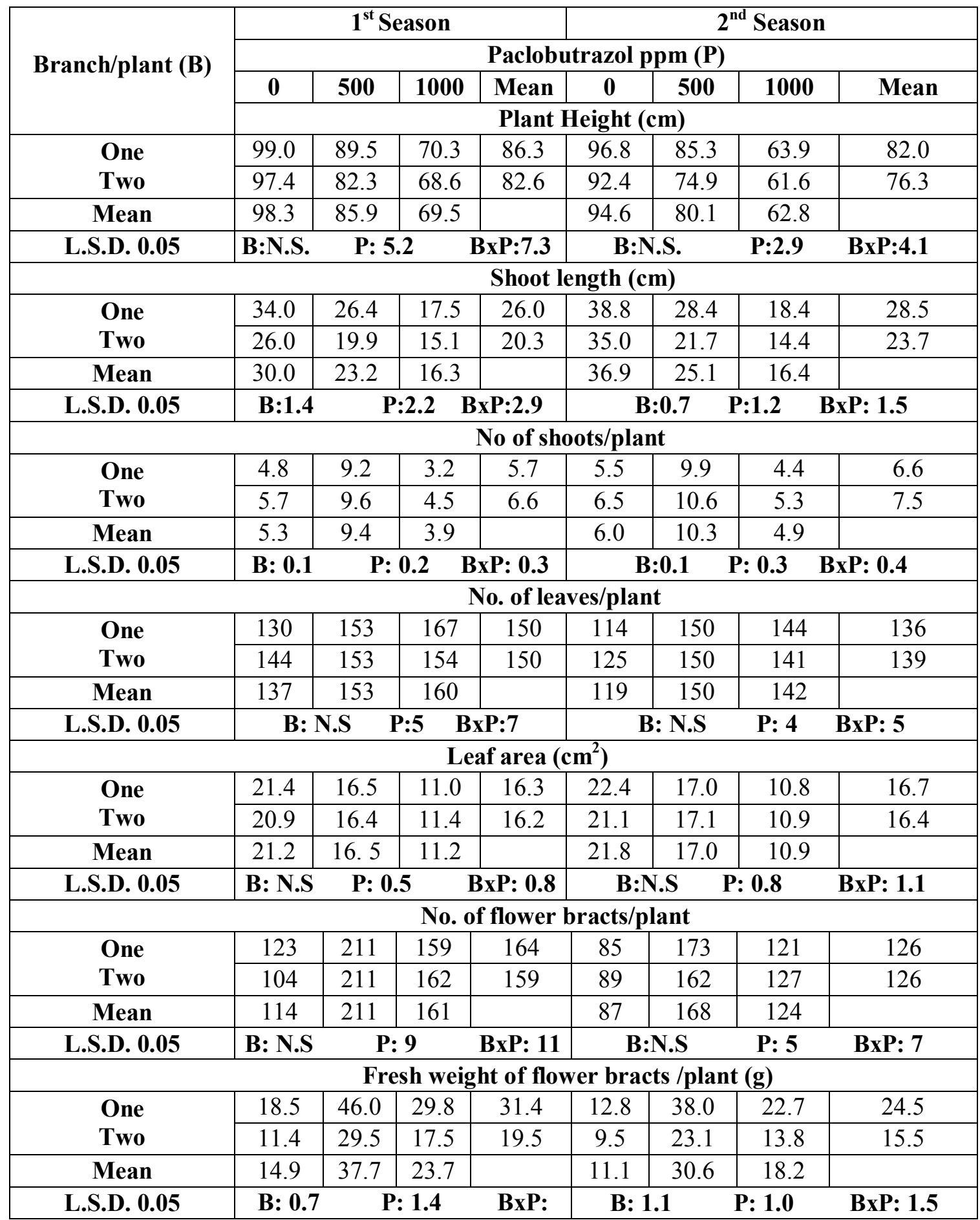


Table 2. Effect of branch number and PP-333 on photosynthetic pigments and total carbohydrates\% in leaves of bougainvillea plants during 2012/2013 and 2013/2014 seasons

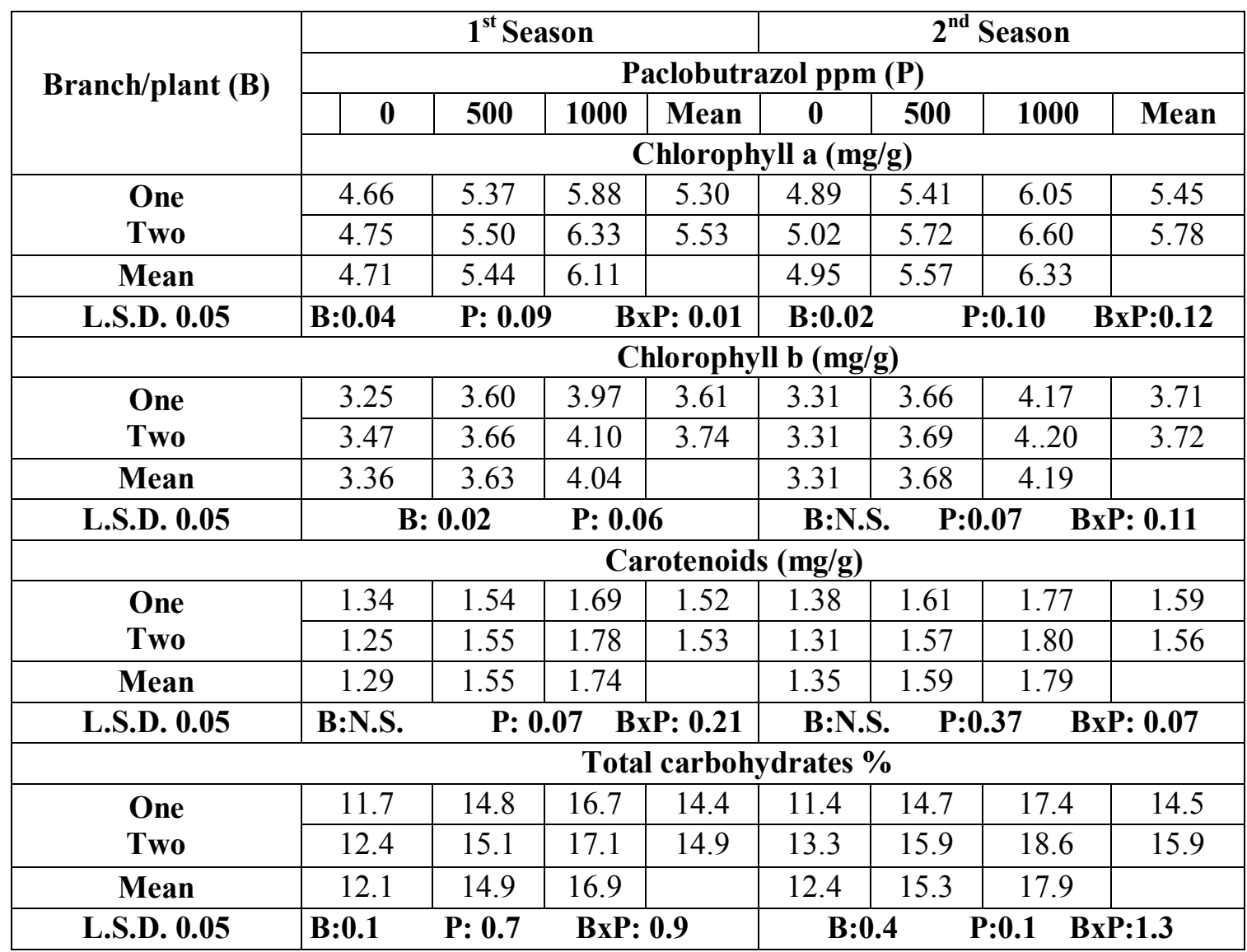

\section{References}

Ahmad Nazarudin, M.R. (2012). Plant growth retardants effect on growth and flowering of potted Hibiscus rosa-sinensis L. J. Trop. Plant Physiol. 4: 29-40.

Auda, M.S.; S.M. Shahin and M.H. ELShakhs (2002). The dwarf barleria: a new pot-plant product. Arab Univ. J. Agric. Sci., 10 (1):319333.

Calatayud, A., D. Roca, E. Gorbe and P.F. Martynez (2007). Light acclimation in rose (Rosa hybrida cv. Grand Gala) leaves after pruning: effects on chlorophyll a fluorescence, nitrate reductase, ammonium and carbohydrates. Scientia Horticulture 111:152-159.

Calatayud, A., D. Roca, E. Gorbe and P.F. Martynez (2007). Light ac- climation in rose (Rosa: .Physiology of growth retarding chemicals. Ann. Rev. Plant Physiol. 15: 271-302.

Cathey, H.M. (1964). Physiology of growth-retarding chemicals. Ann. Rev. Plant Physiol., 15:271-302.

EL-Quesni, F.E.; M.M. Kandil and M.H. Mahgoub (2007). Some studies on the effect of putrescine and paclobutrazol on the growth and chemical composition of Bougainvillea glabra L. at Nubaria. Amer.Euras., J. Agric. \& Environ. Sci., 2(5): 552-558.

EL-Sallami, I.H. (2001). Controlling growth habit of potted poinsettia under two light intensity conditions. Assiut J. Agric. Sci., 32(4): 109-139.

Hansen, J. and I.Moller (1975). Percolation of starch and soluble carbohydrates 
from plant tissue for quantitative determination with anthrone. Analytical Biochemistry 68:87-94.

Heikal, A.A.M. (2017). Controlling Growth of Sanchezia nobilis Plant by Foliar Application of Micronutrients and Paclobutrazol. Egypt. J. Hort., 44 (2):127- 140.

Hussein, S.H.(2013). Regulating growth and flowering performance of night blooming jasmine (Cestrum nocturnum L.) as a pot-plant. M. SC. Thesis, Fac. Agric., Assiut Univ., Assiut, Egypt.

Jaini, R.; T.Janakiram and G.L.Kumawat (2016). Effect of growth retardants on growth and flowering of bougainvillea (Bougainvillea spectabilis) cv. Shubra Indian Journal of Agricultural Sciences 86 (9): 1145-50.

Jaini, R.; T. Janakiram ; K. Swaroop and G.L. Kumawat (2014). Induction of dwarfing in bougainvillea cv Mahara by use of growth regulators. Indian Journal of Agricultural Sciences 84 (7): 802-807.

Karaguzel, O. and V. Ortacesme (2002). Influence of paclobutrazol on the growth and flowering of Bougainvillea glabra "Sanderiana". Ziraat Fakultsi Dergisi, Akdeniz Univ., 15 (1): 79-84 (Hort. Abst., 73 (4): 3905).

Kobayashi, D.K.; J. McConnell and J. Griffis (2007). Bougainvillea. Cooperative Extension Service. College of Tropical Agriculture and Human Resources University of Hawai'i at Manoa. Ornamental and Flowers 38 (10):1-12.

Law, D.M. and R.W. Hamilton (1989). Reduction in the free indole-3- acetic acid levels in Alaska pea by the gibberellin biosynthesis inhibitor uniconazole. Physiol. Plant., 76: 535-538.

LeCain, D.R.; K.A. Schekel and R.L. Wample (1986). Growth-retarding effects of paclobutrazol on weeping fig. Hort. Science 21 (5): 11501152 .

Matsoukis, A.S. and A.G. Chronopoulou-Sereli (2003). An investigation of the effects of environmental factors on Lantana camara L. responses to paclobutrazol and mepiquat chloride. J. Hort. Sci. \& Biotechn., 78(3): 381-385.

Sachs, R.M. and W. P. Hackett (1972). Chemical inhibition of plant height. HortSci., 7:440-447.

Saifuddin, M.; A.B.M.S. Hossain; N. Osman; M.A. Sattar; K.M. Moneruzzaman; and M.I. (2010). Pruning impacts on shoot-root-growth, biochemical and physiological changes of Bougainvillea glabra. Australian J. Crop Sci; 4 (7): 530537.

Singh, A.K.(2002). Growth and flowering in rose as influenced by the application of paclobutrazol. South Indian Hort., 50 (1):124-127.

Snedecor, G.W. and W.G. Cochran (1989). Statistical Methods. $8^{\text {th }}$ Ed., Iowa State Univ., Press, Iowa, USA.

Vernon, L.P. (1960). Spectrophotometric determination of chlorophylls and pheophytins in plant extracts. Anal. Chem., 32: 1144-1150. 
نبات اصص زخرفى من الجهنمية بالتقليم و المعاملة ب PP-333

محمد مصطفى جاد

قسم الزينة ـ كلية الزر اعة - جامعة اسيوط جمط جال

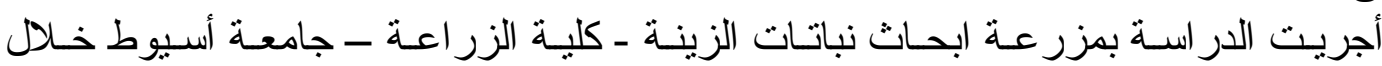

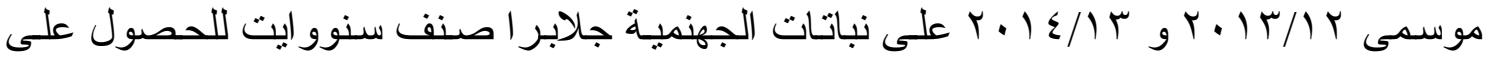

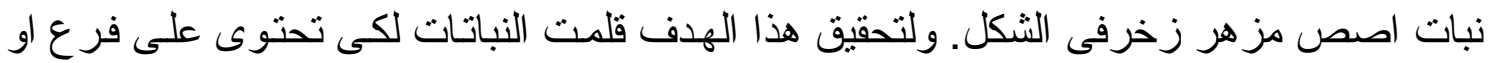

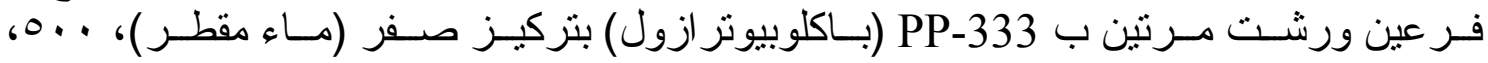

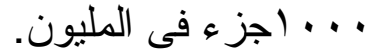

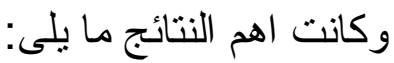

- كانت النباتات ذات الفر عين أقصر ارتفاعا مع زيادة الفيات عدد أفرعها ومحتوى أور اقها من

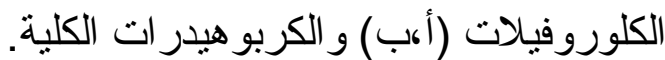

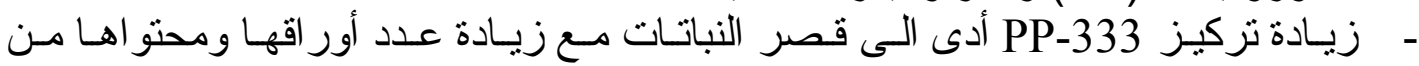
الكلوروفيل و الكربو هيدر ات كماز ادت الاز هار وقل النات وزنها.

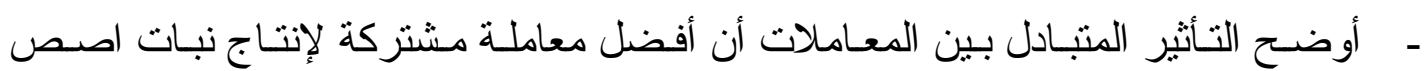

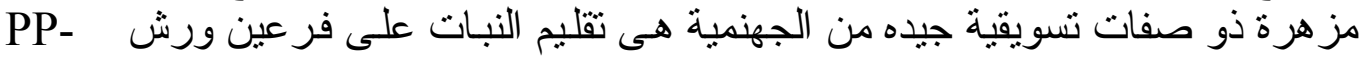
333 بتركيز . .0 جز ء فى المليون. فيما أدى الرش بتركيز . . اجز ع في المليون الى انتاج نباتات مندمجة بثدة مما قلل من

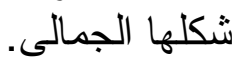

